\title{
1. Introduction: growth, crisis and regime change
}

\section{Hideko Magara}

\subsection{POLICY REGIMES: FRAMEWORK OF THE PROJECT}

For more than two decades, citizens in the developed countries have witnessed massive job losses, lowered wages, slow (sometimes negative) economic growth and widening inequality under governments - left or right - that have implemented similar neoliberal policies. This volume explores the difficulties and possibilities of transitioning from a neoliberal policy regime to another type of regime.

In 2012, Japan's Prime Minister, Yoshihiko Noda of the Democratic Party, and Italy's technocratic Prime Minister, Mario Monti, attempted to put into effect a set of unpopular austerity policies to reduce government debt. This debt had grown to be the largest in Japan and the second-largest in Italy in proportion to gross domestic product (GDP) among the major developed countries. In Japan's election of the House of Representatives in December 2012, Noda's Democrats suffered an unprecedented disastrous defeat. Also in Italy's February 2013 elections, the obvious loser was Monti's group. Electorates tend to punish the incumbent who forces them into austerity policies, particularly during an economic downturn. ${ }^{1}$

The ongoing crisis goes beyond a simple economic crisis. Rather, it can be viewed as a systemic crisis whereby the major actors have stuck to their old strategies, but they are no longer functional. While social and economic imbalances grow, the existing institutional order is eroding. Nonetheless, no one appears to have the ability to construct a new set of institutional forms effectively (see Boyer, Chapter 6, Amable and Palombarini, Chapter 7 , this volume).

In every country, politicians attempt to respond to the demands of various social groups. The configuration of these interests affects the direction of public policies, which in turn eventually influences the nature and the level of economic activity. The ongoing crisis demonstrates how the 
quality of democracy affects the functioning of the economy both positively and negatively.

This book analyses economic growth and crisis. It is not possible, however, to analyse an economy by just looking at the market. Each economic system is embedded within a country's history that is continuously evolving and reflecting technological changes and political struggles in which various interests and institutions are represented and modified. It is, therefore, important to include political criteria in examining this process (Boyer 2011; Bresser-Pereira 2012). Politics predicts the economy.

Is it possible for a democracy to overcome an economic crisis through its electoral mechanisms? Can the electorates in various countries in the face of a crisis make an appropriate choice in an election without falling into populism? Under what conditions can a government convert a crisis of its economy into growth? This volume explores, theoretically and empirically, the possibility of a transition to a new political-economic paradigm by seeking feasible answers to these questions.

Our project is inspired by Adam Przeworski's notion of 'policy regime'. He defines policy regimes as circumstances in which the major political parties of most countries pursue and implement similar policies regardless of their ideological orientations (Przeworski 2001, Chapter 2, this volume). From the end of World War II to the early 1970s, social democratic policies based on Keynesianism covered developed countries as a response to the Great Depression of 1929. After the oil shocks of the 1970s (to 2008), neoliberalism conquered the world. Przeworski (2001, Chapter 2, this volume) shows that a policy history has the following dynamics: first, a new government comes to power, succeeds at imposing a drastic policy innovation and develops a story on the basis of the secret of its success. Opposition parties criticize the government during an election campaign, but the electorate knows that even the opposition will seek the same policies as the incumbent's once the opposition wins the election. The policy differences between the two camps are so small that the winning party will seek to implement policies similar to the previous government's policies. Thus, no policy change occurs even if there is a government alternation, at least until somebody - right or left - introduces a significant policy innovation. When new policies achieve success, the cycle is repeated.

In Przeworski's framework, economic crises are understood as possible triggers for policy innovation. However, political parties need special conditions: (1) they are convinced that the new policies are better than the old ones; (2) voters do not have a good opinion of the old policies; (3) voters believe that the political parties are more concerned with better welfare of citizens than with the new policies themselves; and (4) new policies do not suffer from bad luck. 
Regulationists share a similar view. According to Boyer (2011, p.25), 'during the Golden Age, even conservative politicians sought social democratic policies, while nowadays citizens blame governments for poor economic performances even if their real responsibility is indirect'. Boyer even suggests that in the field of financial policy, the regime has been shifting from a neoliberal stance to something new.

An alternative to neoliberalism is also sought by new developmentalists. Bresser-Pereira (2006) advocates an export-led growth strategy in opposition to the Washington Consensus and 'the third discourse' between bureaucratic left populism and neoliberal 'conventional orthodoxy'.

\subsection{NEW ISSUES UNDER THE NEOLIBERAL POLICY REGIME}

\subsubsection{Heterogeneity}

The 2008 financial crisis and the 2011 Euro crisis hit not only the developed but also the developing countries, demonstrated by Italy's difficult reform initiatives, China's recent economic slowdown and Brazil's recent turn to a zero growth economy. After the 2008 financial crisis, the Group of Twenty (G20) obtained the status of the superior consortium for international economic cooperation, demonstrating the increasing political and economic power of the developing countries. Advanced economies have tried to escape from the crisis by balancing fiscal stabilization and economic growth. With slower economic growth, the developed countries avoided a deterioration of the international balance of payments. In this circumstance, is it possible for the developing economies to maintain rapid economic growth as they did in the past? The newly emerging economies' important role in revitalizing the world economy has been widely recognized, particularly since 2008 . Yet they are still poor on a GDP per capita basis. The advanced economies have sought fiscal stabilization and economic growth to avoid further deficits in the international balance of payments. The newly emerging economies thus require a new growth strategy, different from that based on excessive exports, which expands domestic demand (Rodrik 2009, 2010).

A brief review of the political-economic transformation of Brazil and Italy - which are prototypes of a rising economy and a developed economy in trouble, respectively - will help us understand the state of the world.

Brazil achieved 'miraculous' economic growth in the 1960s and early 1970s. After the oil shocks, however, cumulative government debt rapidly deteriorated. The waves of hyperinflation in the late 1980s and early 
1990s almost brought financial reverses, but the situation dramatically changed. President Fernando Collor, who tried neoliberal reforms, was impeached due to corruption, and Vice President Itamar Franco stepped up to become president. Franco appointed sociologist Fernando Cardoso as Minister of Finance, and successfully managed to stabilize inflation by implementing the 'Plano Real', in which Brazilian currency was pegged with the US dollar. Cardoso succeeded Franco, continued the reforms and got the economy back on a stable track. President Luiz Lula, Cardoso's successor, succeeded in attaining a 'redistribution of wealth' and the 'correction of income disparity' by implementing a series of policies that supported low-income groups, as Brazil vigorously exported agricultural products and natural resources. The people of the new middle class, who were previously part of the low-income strata, expanded consumption and successfully shifted the Brazilian economy from an export-led to a domestic demand-oriented model.

Italy, too, achieved an 'economic miracle' in the 1950s and 1960s. After the notorious 'Italian inflation' of the 1970s, however, Italy's public debt increased in the 1980s. With the debt increase triggered by the Greek crisis, the market even feared the possibility of default. In the short term, Italy avoided default thanks to an anti-crisis policy package of the Monti government. But the economy entered into recession. Monti's austerity policies, which were particularly harsh for those in the low-income strata, were unpopular. Although the Monti government was formed without an election, its survival depended on the support of the political parties.

As for Europe, heterogeneity among the Eurozone members, namely, the North-South divide, has become apparent. The euro has created polarization, with a trade surplus in the North and a trade deficit in the South, and such imbalances cannot be corrected through a purely financial strategy (Boyer 2013, p. 7).

When facing such major imbalances, including unemployment and external and/or public deficits, nearly all private organizations and national institutions take into account the preservation of the competitiveness of the economy in the Nordic countries and Germany. In contrast, in the countries that are more conflict prone, including Greece, Italy and France, public spending and tax concessions have been chosen to soften distributional struggles. The governments of these countries postponed finding a solution to macroeconomic imbalances, putting this off for an unknown future time, simply by increasing public debt.

The Northern small, open economies and Germany can be characterized by open social dialogue, the dynamism of entrepreneurs, political stability, exports and innovation-led growth. Organized collective bargaining sustains competitiveness. Policy makers in these countries put an emphasis 
on education, training and innovation by turning welfare into an asset in world competition through well-designed and patient reforms. Therefore, it was not a difficult decision for these countries to join the Eurozone. The South, in contrast, is composed of medium-size or less-industrialized economies, where the domestic market is monitored and industrial relations are more conflict prone rather than amenable to durable compromises. These countries typically experience unsolvable macroeconomic disequilibria, which stem from high youth unemployment, specialization in services, obsolescence of past industrial specialization, lagging technological innovation, tax evasion and an inadequate welfare system. All these factors have led to large and permanent public deficits. In order to join the euro, the countries of the South needed to completely redesign most of their domestic institutions. Thus, it was difficult for the South to stick to the adjustment programs negotiated with the European Union (EU) and the International Monetary Fund (IMF) (Boyer 2013).

\subsubsection{Exchange Rate}

As dependency theory once emphasized, the Latin American countries, the latecomers that started their economic growth after World War II, depended on foreign capital in order to achieve economic development. After the 1980s, when the political influence of the wealthy countries grew further, owing to the deteriorated balance of payments of the Latin American countries, the growth strategies of the latter were repainted with a neoliberal color. ${ }^{2}$ The Latin American countries were thus placed within a system called the Washington Consensus that was led by the international organizations, the IMF and the World Bank. ${ }^{3}$

However, 20 years later, it turned out that neoliberalism did not promote economic growth of the Latin American countries. ${ }^{4}$ In contrast, the Asian dynamic economies, including China and India, recorded remarkable growth beginning in the 1990s. According to Bresser-Pereira, this difference stems from the fact that the Latin American countries lost control of foreign exchange, which should be the most strategic measure in an open economy, because they too loyally implemented the neoliberal policies advocated by Washington and New York. While most of the Latin American countries adapted neoliberal reforms, the Asian countries, being cautious not to do the same, maintained a surplus in the international balance of payments (Bresser-Pereira 2006, 2010a).

The Latin American countries' experience of losing control of foreign exchange provides many implications for the ongoing euro crisis that Italy and other southern European countries are currently experiencing. In retrospect, it was the European Common Market that enabled Italy to 
achieve remarkable growth in the 1950s and 1960s. Italy, during its economic miracle, enlarged its foreign markets by joining the European Economic Community (EEC) and achieved unprecedented economic growth through a drastic increase of exports (Cardini 2006; Castronovo 1995, pp.408-17, 2010). After 1974, a democratized Spain, Greece and Portugal joined the EEC, and they later came to comprise the Eurozone, along with Italy and the other original EEC member countries. It is ironic that the increased number of member countries eventually brought about the present euro crisis.

Just after the introduction of the euro, the southern European economies seemed to achieve 'growth' due to a sudden increase in the influx of foreign capital. The possibility for economic growth should, indeed, have already existed at the advent of the EU. What actually occurred was that there was an abrupt outbreak of debt crisis in these countries. The citizens suffered from these governments' implementation of a series of strict austerity policies and feeling uncertain about their effectiveness. The main difference from the period of the economic miracle was that a single currency, the euro, had now been introduced.

This common currency has a fundamental institutional vulnerability in that the euro works as if it were a foreign currency: each member country does not have the authority to issue it as sovereign currency (BresserPereira 2011b).

According to Boyer (2013), the euro cannot address the issue of the exchange rate regime. Eurozone member states emit debts in a currency that they cannot issue at the national level. Beginning in 2002, the same interest rate was set for all national public debts within the Eurozone. Thus, some members cannot maintain the economic competitiveness of their economy in the absence of periodic devaluations. The rigidity of the exchange rate has severely penalized national competitiveness, and the divergence between high value-added and skills economies and those limited to more traditional production has become apparent.

The pressures upon the redesign of post-World War II domestic order were strong: the oligopolistic competition at the domestic level was challenged by the globalization of production, the emergence of fastindustrializing economies and the loss of control by public authorities over industrial dynamics. The only solution was internal devaluation, that is, the reduction of indirect taxes, social contributions and finally wages (Boyer 2013, p. 15).

\subsubsection{Wage and Productivity}

During the present systemic crisis, the past compromise, namely, the basic capital-labor institutionalized compromise, has no longer been viable. The 
wage nexus has experienced many transformations: the de-indexing of nominal wage (with respect to inflation and productivity); decentralization and individualization of labor contracts; recurring reforms in the organization and financing of welfare (Boyer 2013).

Equally important as the exchange rate are the problems of low wages and the widening income inequality that have been occurring in the advanced democracies that are in the process of globalization. The poverty ratio is increasing in industrialized countries, including Japan, Italy and the United States. It has been a long time since the wealthy countries entered the capital-saving technological phase, but they have taken the opposite path from attempting to reduce income inequality during the neoliberal era. The background of this negative outcome in the advanced countries was that they were forced to compete with the middle-developed countries that had started exporting industrial products, and that the inflow of population from the latter countries to the wealthier ones began in the 1970s. Reflecting these international constraints, wages in the advanced countries gradually declined. Neoliberal ideology and meritocracy spurred this trend (Bresser-Pereira 2010b).

Poverty alleviation is becoming one of the most important goals for both the developing and the developed countries to achieve. What strategies could lower the poverty rate and at the same time maintain economic growth and stability?

According to McMillan and Rodrik (2011) who focus on how structural changes in each country in the 1990s affected a country's pattern of economic growth, unlike in the rapidly growing Asian economies led by China and India, a wrong shift in labor occurred in the Latin American countries as a consequence of structural changes. In the latter, as firms responded to globalization by curtailing 'excessive' labor, labor shifted from the high (manufacturing) to the low productivity sector (informal and service), which resulted in a slowdown of economic growth. While in Asia, a structural change occurred that increased productivity, in Latin America, a structural change took place that reduced productivity. The difference between Asian and Latin American productivity stems not from the external factor of globalization but from a more local environment: domestic policy makers' choices and growth strategies. In the Latin American case, it is particularly noteworthy that the decline of employment in the manufacturing sector in the 1990s occurred under the neoliberal trend characterized by a widespread liberalization of the economy in which home currencies were overvalued. An overvalued currency squeezes tradable industries and damages in particular the most advanced manufacturing sector.

McMillan and Rodrik's research, mentioned above, implies that the labor shift from the low to the high productivity sector is the key to 
economic development. Their work mainly examines the developing countries, but the problem of displaced workers tending to shift to less productive sectors can occur in the developed countries as well. ${ }^{5}$ Structural change is not an automatic process. McMillan and Rodrik suggest that a national currency must either be competitive or undervalued, or the labor market must make a structural change in order to turn in the correct rather than wrong direction (McMillan and Rodrik 2011).

Recent proponents of structuralist macroeconomics hold a similar view, emphasizing two structural factors that narrow the investment opportunities necessary for economic development: (1) wages rise more slowly than productivity growth and (2) the exchange rate of a home currency cyclically tends to be overvalued. The former constrains the growth of the domestic market. A 'wage-led' growth strategy with wage hikes is feasible on the condition that the increase of purchasing power of the domestic market is large enough to compensate for the reduced profit margin of firms. Wage rises should not be evaluated negatively provided they promote domestic investment. This does not always reduce the profit rate. The overvalued exchange rate, which is the latter factor, is a major barrier against economic development as it prevents modern and effective firms from accessing the international market. An 'export-led' growth strategy is possible if the state can neutralize the exchange rate and maintain it at a competitive level. The government will be hit by a balance-of-payment crisis if it does not manage the exchange rate properly by leaving it just as it is (Bresser-Pereira 2011a).

\subsubsection{Inequality and the Limits of Austerity Policies}

European countries have increasingly tailored their policies to conform to neoliberal doctrines of financial liberalization and market deregulation, particularly following the Single European Act of 1986 and the Maastricht Treaty of 1992. Since the Greek crisis, the euro and policy orientation of the European Central Bank have shown a clear tendency to enforce austerity and often been accused of not making a visible effort to solve the problems of lower growth, greater inequality, a decline in real incomes and increasing unemployment (Schmitter 2013).

In fact, the inequality among social groups has not been easy to address. While chief executive officers (CEOs), top management and the stable holders of various entities have kept their capital intact, the taxpayers have been constantly asked to save the whole country in the name of the public good.

In the Eurozone, there is currently a clear polarization in the perception of the euro among various social groups: the large firm sector and young 
people favor it but low-skilled, low-income people and older citizens are against it (Boyer 2013, pp. 18-20). This divergence in people's perspective implies that the euro has led to a deterioration of democratic legitimacy. Indeed, a worsening of unemployment rates and the polarization between rich financiers and professionals, on the one hand, and the poor sector, on the other, show the sheer necessity to return to a well-controlled real economy in response to citizens' demands for a more responsive democracy.

In these circumstances, austerity policies can be highly detrimental to the economy, as the past IMF programs in Asia and Latin America demonstrated. Austerity policies tend to depress demand; depressed investment may well reduce potential growth; public finance of the weakest economies may become more unstable.

Capital moves beyond borders faster than world trade and accordingly the exchange rate deviates far from the rate that would warrant the competitiveness of the domestic economy. The germ of the present crisis lies, in reality, in the weakness of the domestic productive potential.

Financial markets are highly ad hoc, and they oscillate between excessive optimism and excessive pessimism along with the ups and downs of the economy. It is dangerous to assign to the financial markets the task of disciplining each country's public finances. Governments should impose certain restrictions on global financiers' speculative moves and respond to the needs of the real economy and to new social demands from their citizens (Boyer 2013).

If austerity policies result solely in a prolonged recession, the feeling of unfairness among most voters will be easily exacerbated. When unemployment leads to be a rather residual variable, it hinders domestic demand and eventually triggers social conflicts and political turmoil.

Thus, governments should place the first priority not simply on making and implementing a series of correct policies but on the formation of a social and political consensus that is simultaneously compatible with the requirements of a more globalized economy and the pressing demands on the part of citizens.

\subsubsection{Political Uncertainty}

The neoliberal policy regime has destroyed the climate for superior economic performance along with greater social justice, which had been fostered under the social democratic policy regime.

In many developed countries, extremist parties and movements have been achieving a certain degree of electoral success. Schmitter (2013) warns of 'morbidity symptoms' in industrialized democracies, in which citizens are more likely to abstain from voting; less likely to join or even 
identify with political parties, interest groups or professional associations; more likely not to trust politicians in general; and much less likely to be satisfied with the present forms of politics and the benefits they receive from public agencies (p. 12).

Recently, the electorate in various countries has demonstrated an unprecedented tendency to eject incumbents from office. In developed countries, democracy was in the past constructed on the basis of hegemonic parties that ruled for consistent periods of time. Now, these parties have either disappeared or have lost hegemony and only govern. The tenure of most governments in industrialized democracies has become unstable. Voters show a greater sympathy towards the populist parties of either the right or the left. Such parties are the byproducts of established political parties that have become unable to represent citizens' demands or articulate feasible future blueprints for the polity as a whole. These new populist forces can push centralist parties into adopting items from their platforms. Thus, it has become increasingly more difficult for established parties to form coalition governments. Democracy in the developed countries may well survive the current economic crisis, but it will have to change its nature; it will have to become even more different from the form of democracy that the left and the right constructed after World War II. The developed countries must find and institutionalize a new social contract and a more regulated political economy, and new channels of democratic participation and mechanisms of accountability to their citizens (Schmitter 2013).

\subsection{TOWARDS A NEW POLICY REGIME?}

\subsubsection{New Social Alliance?}

After the recent economic crisis, Przeworski's notion of a 'policy regime' gained new prominence because it offered the possibility of exploring a post-neoliberal paradigmatic shift. ${ }^{6}$ Przeworski's framework encourages researchers not only to reflect on neoliberalism but also re-evaluate certain elements of social democracy.

As Przeworski argues, the developed democracies shifted their policy regimes from a social democratic to a neoliberal orientation between the post-war period and now. However, there was a variety in each country's growth pattern. The factor of time and timing plays an important role in an analysis of economic growth, crises and the political responses of the developed and the developing countries, as the framework of "product cycle' (Vernon 1966) shows. In addition, particular attention should also be paid to the changes in the consensus that each country formed and in the 
social alliances that backed such consensus (Amable et al. 2012). Various institutional reforms to overcome economic crises and to formulate a new paradigmatic change for growth require the formation and the sustainability of social-political coalitions under a democratic system.

How did the developed countries change the nature of their consensus? Under the 'Fordist growth' pattern that typically emerged in the superpowers after World War II, owing to the consensus between employers and workers, the increase in real wages institutionally responded to the rise of productivity. The potential of this model, however, became depleted as time passed, and fell into a vicious circle under the trends of globalization and financial liberalization. The responses taken by the European small countries were different. They maintained the international competitiveness of their enterprises by setting a proper wage level in the export sector and achieved export-led growth. It is particularly noteworthy that the Scandinavian countries created a new virtuous circle characterized by welfare state rejuvenation and technology innovation-led growth, by responding to new societal demands and by creating new collective rights, including gender equality. ${ }^{7}$ The system in which losers are institutionally compensated by winners accelerated technological innovation, maintained the countries' competitiveness and thus enabled there to be compatibility between social justice and dynamic efficiency (Boyer 2007).

Such a virtuous circle between welfare and economic growth can be observed not only in some of the developed countries but also the developing countries. For instance, the welfare policies of Brazil's Lula government that have been targeted at the masses, who make up the majority of Brazil's population, show that changes in the political dimension are a precondition for effective poverty policies. This is a case that represents the positive effect of democratization on poverty reduction policies (Draibe and Riesco 2009). In fact, Brazil's GDP per capita gradually increased under the Lula administration (2003-11), although it had decreased in the 1990s (Figures 1.1 and 1.2).

After a painful period of adjustment, a return to an economic recovery should be reconciled with the fulfilment of the social demands of citizens, including job creation and the preservation of the education and healthcare systems. Boyer (2013) argues that the necessary complementarities to be reorganized between the international and domestic levels include the financial strategy and the recovery of productive investment, the shortterm reduction of public finance imbalances and the long-term strategy of research and development and permanent scaling up of skills, the monetary policy and the national budget and tax politics. The creation of these institutions can be the expression of the formation of political alliances under the hegemony of a leading collective actor. 


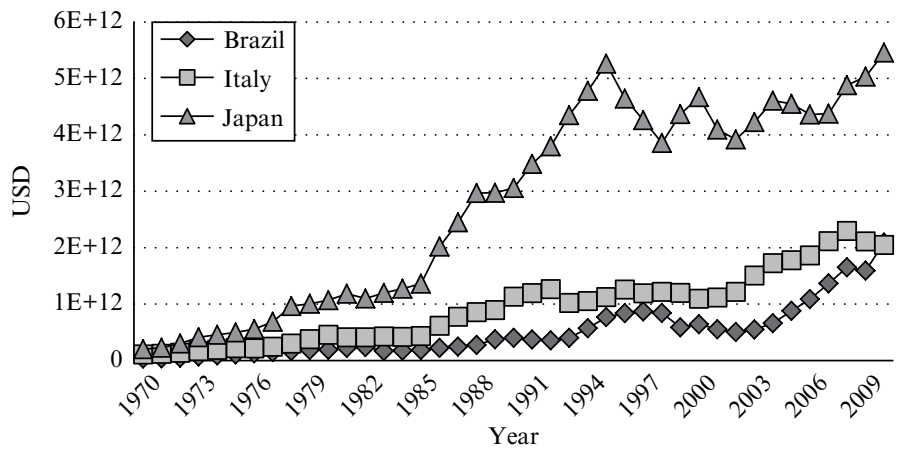

Source: United Nations, National Accounts Main Aggregates Database (2012), http:// unstats.un.org/unsd/snaama/Introduction.asp (accessed November 2013).

Figure 1.1 GDP of Brazil, Italy and Japan in US dollars

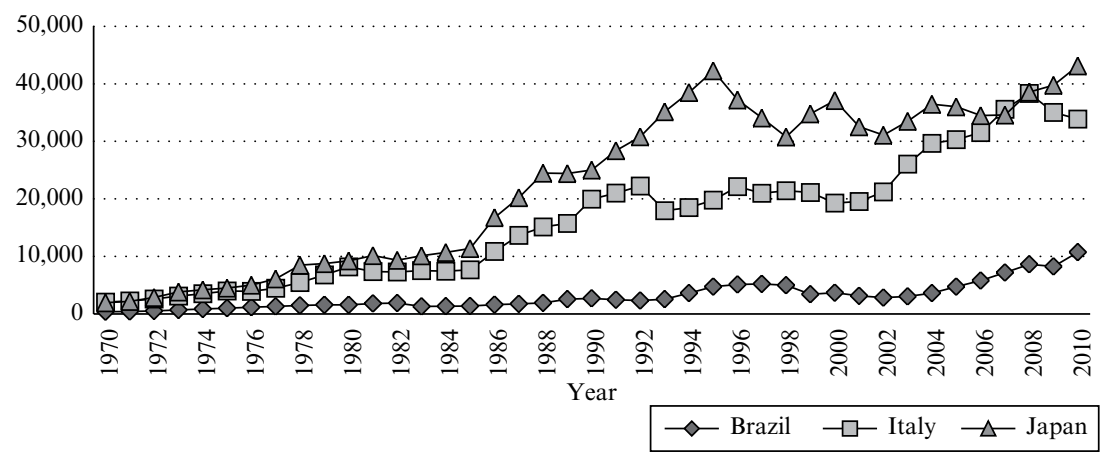

Source: United Nations, National Accounts Main Aggregates Database (2012), http:// unstats.un.org/unsd/snaama/Introduction.asp (accessed November 2013).

Figure 1.2 GDP per capita of Brazil, Italy and Japan in US dollars

\subsubsection{Escaping from El Angel exterminador}

According to Bresser-Pereira (Chapter 3, this volume), the mechanisms that lead to a hegemonic policy regime are not simple. First, there is a crisis of the previous policy regime and second, there is a strong intellectual elaboration followed by rational persuasion and effective co-optation. After the new ideas have acquired legitimacy, people almost unconsciously conform to 'one best way'. The hegemony has now become one of El angel exterminador $^{8}$ (the exterminating angel). 
Facing an obvious economic crisis, people commonly come to think that existing institutions cannot be retained without reform (Fukuda, Chapter 12, this volume). The neoliberal policy regime, which has destroyed the nationwide social democratic consensus on growth and equity, is said to be dominated in the United States by only 2 per cent of the whole population. Why was it so difficult for ordinary voters to bring an end to the era of neoliberalism, despite their huge numerical advantage? Why do the voters not turn the rules of the game from that of a notable disparity between a small number of winners and an ever-increasing number of losers to a winwin situation again?

Indeed, one leading actor might change the rules of the game to his or her benefit and find a way out of the crisis (Boyer 2013, p. 55). One person, hopefully one leading politician, needs to be courageous enough to say 'Let's get out of here together', just as Silvia Pinal successfully persuaded the people in the room who were obsessed by the angel exterminador and who somehow believed that they were cooped up.

Political leaders, on the one hand, need to construct a new social-political coalition that provides stable electoral support for a new policy regime and, on the other hand, sweep aside various types of populism. In fact, the economic policies determined by politicians who want to be re-elected tend to provoke populism. In this context, the notion of democratic accountability (Przeworski et al. 1999) will have greater significance. Democratic politics still connote fundamental limits for self-governing electorates (Przeworski 2010). In this sense, it is ironic that, precisely when a large number of aspiring new democracies were emerging across continents, the established democracies of the rich countries were hit by a series of crises.

Can the electorates overcome such democratic vulnerability? Can a government that tries to maintain the exchange rate skillfully shift the policy regime in a welfare-oriented direction? Brazil's Lula government was on the verge of a leftist populism, but he managed to lead the economy towards growth. Italy's Monti government is composed of experts who only indirectly suffered from electoral constraints. However, the labor market reform showed that even the Monti government, consisting of elite non-politicians, could not escape from the difficulties that exist in a democracy.

As we have observed, developed countries have been tackling the shared problems of globalization, increasing public deficits and the structural changes in society. After the financial crisis of 2008 , and particularly after the sovereign debt crisis of 2011, the international norm may be shifting from a straightforward neoliberal hegemony to 'something else'.

Przeworski's notion of a 'policy regime', like Hall's concept of 'policy ideas' (Hall 1986), underlines that policy innovations require not only 
political leadership but also the very creation of a new economic theory in order to break a critical juncture of economic stalemates.

It should be noted, however, that Przeworski explicitly introduced the electoral variable in his framework. Whether or not new policies are successfully formed and implemented is strongly constrained by political factors. As the argument of democratic accountability shows, honest politicians coexist with dishonest politicians during electoral campaigns, and even after being elected, the former can make a mistake in determining a policy direction. The voters, too, can be short-sighted or easily fall into populism. How can the evolving democracy of both the developed and the developing economies be fluctuating between growth and crisis?

Whether or not a long-awaited policy innovation will come to fruition is still unclear. In any case, the quality of democracy is the key to an epochmaking policy innovation. The most important issue for democratic voters is to find out which political forces and coalitions can achieve welfare provisions, poverty reduction and economic growth through a series of institutional adjustments, and to firmly support and encourage them.

\subsection{STRUCTURE OF THE BOOK}

This volume is a new attempt to analyse the interaction between the economy and politics under the neoliberal policy regime and explore the possibilities for paradigmatic changes. The book is composed of three parts: (1) theoretical explorations; (2) social coalitions and elections; and (3) global governance and policy areas.

\subsubsection{Theoretical Explorations}

In Part I, Przeworski in Chapter 2 analyses the conditions conducive to policy innovation. According to him, a 'policy regime' is an equilibrium whereby different parties provide and implement similar policies. He attempts to explain the mechanism of policy innovations and emphasizes that these are based on blueprints and/or powerful institutions. Both Keynesianism and neoliberalism were historically unprecedented inventions. Then, he asks, why can someone deviate from an established policy regime?

According to Przeworski, the only cases of true innovation were the Swedish discovery of demand stimulation after 1932 and the ThatcherReagan neoliberal experiment after 1979, in which 'the innovators knew only vaguely how radical their policies would become but in both cases they informed voters that they have something new in mind.' 
Przeworski underlines that Thatcher's policy package was not successful by all criteria. Indeed, the economic performance of her government was a dismal failure. But she had an entire vision of society and her experiment constituted a dramatic break with the past that had astonishing international repercussions.

Przeworski implies that the most consequential policy is the one that changes the rules of the game. Thatcher changed the trade-offs between redistribution and growth through the opening of a capital account. This policy forced the two parties to reduce the extent of redistribution they proposed. 'Once the decision was made, the entire spectrum of feasible policies was moved. Even left-wing voters had to opt for less redistribution because redistribution became more costly.'

The general economic performance under neoliberalism was universally bad. Its distributive impact was that the rich were getting richer. Przeworski poses an intrinsic question: Why did voters re-elect governments that made most of them worse off?

He also implies that the neoliberal policy regime was dominated by fear. 'What matter more are risk postures, specifically, the fear of losing jobs.' Do electorates elect and re-elect neoliberal governments because they are offered no serious alternatives? Przeworski emphasizes the paucity of new ideas. Although there is room for action, all the actors, including politicians, government officials and economists, seem to have suffered a 'failure nerve'.

In Chapter 3, Bresser-Pereira argues that policy regimes are formed when a certain class coalition acquires a clear ideological hegemony to the extent that people believe as if they live in a time of the 'one best way'. The policy package chosen by such regimes reflects the constraints that are linked to the interests of the class coalition in power.

The 30 Golden Years of Capitalism, to use Bresser-Pereira's term, can be understood as a period of organized techno-bureaucratic capitalism in which managers and professionals shared power and privileges, and a broad cross-class compromise was reached between business entrepreneurs, workers and the techno-bureaucratic middle class. In contrast, the neoliberal class coalition was a narrow one that united the rentiers, the financiers and the top executives of leading multinational enterprises. The latter is not compromise but domination. In that case, was the social democratic policy regime weaker than that of neoliberalism, in terms of the strength of the belief in 'one best way'? Moreover, does this stem from the difference between the compromise of the former and the dominance of the latter?

Bresser-Pereira poses an important question: Why do policy regimes involve a belief in some kind of 'one best way' or 'only one way'? As a 
matter of fact, it was very difficult to see alternatives in the neoliberal years. According to Bresser-Pereira, hegemony constraints are effective because the coalition in power can impose its view and policies on others. These are the fundamental constraints of a policy regime because they define its historical moment. Bresser-Pereira also underlines that in developing countries the hegemony of developed countries was coupled with the dependency of local elites. The hegemony constraints worked in relation to such elites.

Bresser-Pereira suggests a possible new policy regime that would emerge as a pact among business entrepreneurs, the public bureaucracy and workers, under which wages would increase with productivity and social inclusion would be sought through the welfare state.

In Chapter 4, the present crisis is viewed from a dynamic historical perspective of capitalist development by Yamada. He observes that structural crises tend to last for 10-20 years, following periods of durable growth that last between 20-30 years. Yamada poses a question: In what historical topology is the ongoing world economic crisis situated? The world history of capitalism can be understood as the alternation of growth and crisis, or the alternation and change of growth regimes. According to Yamada, capitalism has been changing its development model about every half-century. He particularly focuses on the United States, the hegemonic country that led the neoliberal policy regime. The capitalism of this hegemonic power has experienced structural changes every several decades.

In the middle of the Fordist crisis, the United States initially prioritized a firm's level of competitiveness, which led to wage austerity and the degradation of employment. Additionally, he looks at American consumers, who enjoyed access to low-priced imported goods. The United States liberalized the financial sector, giving that sector a particularly important position in the economy. The conception of such a positional superiority of finance spread even among workers as pension funds became more common.

Yamada argues that corporate governance is an institutional apparatus that connects an increase in asset prices to an increase in financial returns. This eventually led to a domination of management by finance. The once-prevailing capital-labor regulation was replaced by a stockholdersovereignty type of regulation; the traditional capital-labor compromise was surpassed by a finance-management compromise. Most importantly, he emphasizes that the hegemony, that is, the 'dominant social block', shifted from the previous capital-labor alliance to the financemanagement coalition.

Yamada stresses that the finance-led model is characterized by a lack in both universality and stability. The government programs enacted to 
rescue the financial institutions, in response to the 2008 financial crisis, have resulted in further fiscal or sovereign debt crises in several of the Eurozone countries. He asserts that only a new growth regime and mode of regulation on the basis of radical structural change will be able to get these economies out of crisis.

In Chapter 5, Nishi theoretically complements Yamada's argument concerning economic growth. Nishi explores the impact of macroeconomic policies on economic growth. He sets up a dynamic post-Keynesian model that has government and central bank interventions. By defining the economic growth regimes as the relationship between economic growth, income distribution and government debt finance, he creates several varieties of regimes. The income distribution and/or growth regimes have two subtypes: the wage-led and the profit-led regimes. The debt-growth regimes also have two subtypes: the debt-led and the debt-burdened regimes.

Nishi views the policy regime as an equilibrium in which policies become similar across different parties. He examines whether such a political constellation has a positive impact on economic performance, by investigating macroeconomic policies on the basis of different types of post-Keynesian interest rate policy rules, such as the Smithin rule, the Pasinetti rule and the Kansas City rule.

Nishi argues that different policy rules have different effects on the economic growth rate. If the policy regime is defined as equilibrium in which different parties seek similar policies, such a regime may not always improve economic performance. According to Nishi, macroeconomic policies should be compatible with the type of growth regime in which they are implemented. An economic policy can be effective under one economic growth regime, but may not be effective under another, so sticking to the same policy may not produce optimal results. He asserts that there is no single best policy for growth and that policy makers should choose economic policies appropriate to the economic growth regime.

In Chapter 6, Boyer observes significant diversity across countries in terms of style, interest mediation, core objectives and privileged tools, and traces back the past trajectories of various types of capitalist democracies. $\mathrm{He}$ also examines interactions between economy and politics and offers prospects for some possible transitions to new political economic paradigms: typical liberalism, social liberalism and renewed social democracy.

Boyer labels the neoliberal policy regime as a finance-led regime characterized by inequality and instability. The top management of large companies has become associated with global financiers to shift greater financial risks to wage earners, thereby stabilizing the return on equity and shared capital gains through stock options and other instruments. Since the 1990s, this process of financialization has directly affected economic evolution, 
excluding wage earners from the policy-making alliance. For Boyer, this exclusion of a large social group is evidence of de-democratization.

Within the regulationist framework, Boyer explains the mechanism of regime change. According to him, a dominant policy regime appears as the necessary complement of the development mode. Because the success of a development mode generates a gradual loss of structural stability, such smooth trajectories cannot be constant. Thus, it is not possible to restore the previous regime by repeating past economic policies. The interaction between policy and economy varies drastically between stable periods and crisis periods. During crises, the ongoing economic paradigm is largely falsified, with past institutions no longer having the power to trigger an economic recovery.

Just as Bresser-Pereira (Chapter 3), Amable and Palombarini (Chapter 7) and Ido (Chapter 9) argue in this volume, Boyer too suggests that social classes and interest groups struggle and compete to support the redesign of a declining institutional architecture. For Boyer, the emergence of new regimes from the interaction of heterogeneous and conflicting interests is not a simple process. There are unintended outcomes that result from the process of trial and error to mutually adjust a policy and an economy. In democratic configurations, the negotiation among various interest groups can be a good strategy towards achieving a viable construction of institutional forms. Once established, political-economic regimes may be converted into government paradigms that can be emulated elsewhere.

Boyer emphasizes the need to ignore the illusion that the 'one best way' for socioeconomic regimes will soon emerge, and underlines the importance of including most socioeconomic groups in the political process, since this contributes to the long-term viability of a regime.

\subsubsection{Social Coalitions and Elections}

In Part II, Chapter 7, by analysing the recent political-economic changes in Italy and France, Amable and Palombarini propose the political economy approach, in which the viability of a socioeconomic model depends on its capacity to regulate social conflicts. Under a political equilibrium, social conflict is regulated and the contestation coming from people whose demands are neglected by the political leadership is limited to a minority position of the political representation space. Amable and Palombarini label the groups whose main demands determine the direction of public policy as the dominant social bloc (DSB). According to the authors, a political equilibrium exists when there is a stable DSB composed of several groups that support the policies implemented by political parties. A political crisis is a situation in which the previously dominant alliances, which 
controlled the main directions taken by political action, have been broken. When the existing institutional structure prevents not only the renovation of the former DSB but also the emergence of any new dominant bloc, the situation becomes a systemic crisis.

Amable and Palombarini analyse the policy changes in France and Italy during political and systemic crises as a series to construct a dominant social alliance. In this context, policies implemented by François Hollande and Mario Monti represent a mediation aimed at building a relatively new social alliance, which they call the bloc bourgeois because it excludes the popular classes. According to Amable and Palombarini, the French left has been sandwiched since 1983 between a demand for the pursuit of European integration and for an expansionary macroeconomic policy, and has constantly sacrificed the latter. In the Italian case, the industrial and economic structure prevented the left from taking office until the mid 1990s. During the 1990s and the 2000s, the Italian left tried to build a producers pact between employers and the most protected faction of workers. The pact, which put a higher priority on the constraint of European integration, failed because of its recessionary outcomes. In this chapter, the EU may implicitly represent the phenomenal consolidation of the neoliberal policy regime at a supra-national level. From the rightist side, Nicolas Sarkozy and Silvio Berlusconi alternatively attempted to escape from the political and systemic crises through a set of neoliberal macroeconomic policies and structural reforms. However, radical neoliberal policies were no longer successful.

The bloc bourgeois, which emerged under the Monti leadership in Italy and under Hollande in France, is composed of the skilled middle and upper classes. Amable and Palombarini suggest that these governments pursued a strategy of neoliberal reforms, particularly in the labor market. They imply that the recent promotion of Germany as a model to follow is linked to the emergence of the bloc bourgeois. Can the German model be a new policy regime? The social base of the bloc bourgeois may be too narrow and fragile to make a stable alliance.

After the Korean founding election of 1987, the first democratically elected president continued a 'developmental state policy regime'. Amidst the economic crisis of 1997, the center-left Kim Dae Jung government introduced a new neoliberal policy regime. In 2008, President Lee Myung Bak responded to another economic crisis that originated from Wall Street without implementing any policy innovations. In Chapter 8 , Im explains why political leaders of different party stripes made similar political choices during a period of economic crisis. Im traces the trajectory of the introduction, stability and demise of the developmental state policy regime from the authoritarian to the democratic era. Further, he examines why 
previously progressive leader Kim adapted and pursued neoliberal policy innovations to consolidate them as a new policy regime.

Kim launched a radical neoliberal policy change despite his promise to the Korean electorate to not follow the conditionalities imposed by the IMF. Im explains Kim's policy switch as being related to the Korean leader's conviction that the main causes of economic crises lay in the developmental state, a 'crony capitalism', in which the government provided monopoly rents to huge conglomerates (chaebols) that concealed opaque corporate governance through dense political patronage networks and shared shady rents with politicians and bureaucrats. Kim promoted massive neoliberal reforms, including labor market reform and put his country's economy on the right path again.

However, the course that Kim followed was an American-style democracy and market economy. His successor, Roh Moo Hyun, faithfully followed Kim's neoliberal direction, and the conservative Lee Myung Bak, President-Elect in 2007, deepened the neoliberal policy regime. Their choices, however, had a negative result. Social inequality expanded, and the whole society became polarized among the various classes. Im implies that the center-left progressive governments of Kim and Roh could neither reduce income inequality nor contribute positively to the realization of a fair society, and he emphasizes the importance of new policy innovations that aim for a 'social compensation policy regime'.

In Chapter 9, Ido shows the difficulty of a policy regime change that requires the construction of a new social alliance. After the collapse of Lehman Brothers, the Democratic Party of Japan (DPJ) won a landslide victory in the 2009 election. The DPJ proposed throughout the campaign a radical policy shift, including a child allowance, a guaranteed minimum pension, income support for farmers and no consumption tax hike. Initially, the DJP-led coalition government was active in pursuing its policy package. However, as concern over Japan's huge public debt grew against the backdrop of the European sovereign debt crisis, the coalition government placed a much higher priority on financial reconstruction while downplaying its commitment to narrowing economic inequality. Faced with the harsh reality of financial constraints, the DPJ leadership chose a policy switch.

Ido attributes the stability of a policy regime, despite waves of economic downturns, to the unchanged position of the median voter. $\mathrm{He}$ suggests that feedback mechanisms link a social class coalition to a policy regime. By promoting economic growth and by cementing its social class coalition through the distribution of the wealth brought about by economic growth, political parties play a pivotal role in the feedback mechanism. Even during economic crises, a policy regime can persist as long as the members of the social class coalition benefit from it. He also argues 
that in order for a policy innovation to successfully convert into a new policy regime, a challenger political party needs to form an alternative social coalition. When a challenger party succeeds not only in convincing the voters of the rightness of new policy ideas but also in forming a new social coalition, the position of the median voter will change and society will accept a new policy regime.

After the 2009 election in Japan, many expected that a new coalition among organized workers and urban dwellers would replace the old proLiberal Democratic Party (LDP) coalition among managers, shopkeepers, farmers and rural communities. However, this did not come true. On the contrary, the LDP won a landslide victory in the 2012 election to return to power. Did the DPJ not have the political skills to achieve success? Did it suffer from bad luck due to the earthquakes in 2011? Ido implies that the DPJ did not have in-party congruency. Its leaders and parliamentarians scarcely shared the basic ideals, values and objectives that lay behind the party's radical campaign in the 2009 election.

In Chapter 10, Yanai analyses a dramatic change in government in the United Kingdom in 2010. There have been many historic changes, including in the United States, Japan and Italy, since the Lehman Brothers collapse in 2008. In the United Kingdom, the Labour Party lost its leading position in Parliament and was obliged to let the Conservative Party take office again, although it had to do so in coalition with the Liberal Democratic Party. Yanai asks why the British voters punished the incumbent in the 2010 election, that is, why did they not give the majority of parliamentary seats to the Conservative Party.

Yanai employs economic voting theory and attempts to explain individual citizens' choices in the 2010 election. He introduces a new dimension, that is, voters' perceptions of the financial crisis. On the basis of Przeworski's argument, Yanai proposes a hypothesis: a new policy regime can emerge when voters are faced with a crisis. If the voters pursue such a new regime, their voting behavior can deviate from the ordinary.

Through an analysis of the survey data of the 2010 UK general election, he shows that the crisis variable, along with three other variables of the economy, was important for the British electorate. The four independent variables did not always have an impact on voters' choices. Those who were affected by the financial crisis were more likely to support the opposition rather than the incumbent, in contrast to those who were immune to the crisis. An analysis of aggregate data suggests that the frequent government turnovers since 2008 can be understood as the results of retrospective voting. The incumbents have been punished for worsening countries' economies. Although different factors matter for different sets of options, the financial crisis was in this case a cause of Labour's electoral defeat. 


\subsubsection{Global Governance and Policy Areas}

In Part III, Chapter 11, Martinelli shares the same insight with Boyer, Bresser-Pereira, Yamada and most authors in this volume: in the neoliberal policy regime, a new alliance was formed between managers, financiers and shareholders.

He particularly focuses on the mechanism by which market-driven capitalism becomes hegemonic, by introducing the notion of a cognitive framework. According to Martinelli, the most important feature of the global crisis is the cultural orientation that prevailed among the financial, corporate, bureaucratic and intellectual elite, namely, the neoliberal conception of the self-regulating market.

In the cognitive framework, the virtual economy predominated over the real economy. Most economic practitioners embraced the illusion that risks could be avoided by shifting them into other subjects, which falsely legitimized the new high-risk products of financial innovation. Market fundamentalism and the lack of regulation greatly supported such an illusion. Global capitalism has witnessed during the last 30 years excessively unregulated markets, a growth of inequality and lack of government control or redistributive efforts.

Martinelli argues that a political-sociological factor was at work behind this phenomenon, namely, the successful lobbying of a powerful coalition of interests. Policy makers were rather impotent in the face of the conscious pressures of specific interest groups composed of big investment banks, commercial banks, hedge fund managers, financial analysts, corporate executives, auditing firms, and consultants to corporations, rating firms, lobbyists, lawyers, politicians, bureaucrats, academic think tanks, opinion makers and the media. These elites were able to lobby effectively and they weakened the traditional rules and control systems, fully utilizing their wealth, power and prestige.

Martinelli stresses the difficulty of making a policy change from neoliberalism to something new because of the fast-rising costs of elections that are accompanied by frequent political campaigns. The demand for money has inexorably increased, pushing politicians towards continuous fundraising activities. He emphasizes that the lobbyists of shadow finance have been successful in dismantling existing controls and blocking new regulatory measures. This contributed to the deepening of the global crisis.

Martinelli explains why the Obama administration failed to shift from the neoliberal policy regime to a new regime, although Barack Obama had new ideas and the public had already recognized the limits of neoliberal policies and detested them. In fact, Obama did try to form a new political coalition that could limit the power of the leaders of finance. Why did he 
fail? Martinelli solves this puzzle by focusing on the specific nature of contemporary policy making in the United States. He suggests that the power of business elites is particularly strong in the United States. The cultural dimension seems to be more influential there because politicians have to win elections, and for that reason they need the culture, which constantly secures for them a broad support of the electorate.

It is irrational of the voters to elect and re-elect politicians who support neoliberal policies favoring only 2 per cent of the total population. Perhaps the voters embrace some illusion that comes from the cognitive framework that business and finance elites have succinctly created.

Particularly since the global economic crisis occurred, the majority of the EU member states have been moving in the direction of forming a similar set of policies. Why is this the case? In Chapter 12, Fukuda explores the background to the global economic crisis and the formation of a labor policy regime at the EU level. He examines the reasons why similar market reforms emerged in various EU countries and in Japan, and analyses to what extent labor market reform has been necessitated by the global economic crisis.

Since the collapse of Lehman Brothers in 2008, the 'embedded neoliberalism' policies of the EU integration process have been faced with new realities: the EU's goal of creating a 'social Europe' has become a mere façade, and social security has been given a lower priority in the countries that were forced to adopt austerity measures. The expansion of the EU has led to antagonism among wage earners, and workers have been pushed into the 'competition to lower labor costs'. This phenomenon also occurred in Japan. Have the European countries and Japan shifted from a Keynesian welfare national state (KWNS) to a Schumpeterian workfare post national regime (SWPR)?

The developed countries have been spending public funds to save banks and provide them with financial assistance aimed at protecting their own nations' financial systems. Because political leaders hesitated to regulate the financial industry immediately after the fall of Lehman Brothers (in Japan's case, after the bubble burst of 1991), the budget deficits and public debt of European countries and Japan swelled dramatically. Both the EU's and Japan's subsequent coping measures were toyed with by financial markets and credit-rating firms, and wage earners were ultimately forced to pay the price. Fukuda alerts us that the neoliberal policies chosen by the political leaders of the EU and Japan may result in larger wage and social security disparities between insiders and outsiders.

Fujita challenges structural determinism. She traces how the supra-class idea was effectively encapsulated in Sweden and how political leaders fought for equality and democracy. In the 1930s, reform ideas were invented 
as responses to the economic and population crisis. Sweden had excellent economists. The country's political leaders and economists proposed a set of counter-cyclical fiscal policies, which later came to be called 'Keynesian policy before Keynes'. Fujita stresses that a new fiscal policy was widely accepted by the general public. The socialization of consumption, or the investment in human capital, contributed to economic efficiency and social fairness and resulted in higher labor productivity.

After World War II, the Swedish Social Democratic Workers' Party (SAP) was quick to shift from a 'red-green alliance' with the Farmer Party to a new alliance with white-collar workers. In the 1950s, a new economic model united selective economic policies with universal welfare policies. This was a combination of solidaristic wage policy and active labor market policies from the supply side. In Sweden, Keynesian macroeconomic policies on the demand side were sought along with Rehn-Meidner model's microeconomic policies on the supply side.

Further, Fujita focuses on the point that the SAP succeeded in obtaining greater support from the middle classes by redefining the meaning of universalism from that of the eradication of poverty to a more practical goal, the maintenance of current income. Swedish social spending started to drastically increase.

However, Sweden experienced an economic recession, a structural crisis, stagflation and a fiscal deficit in the 1970s. A substantial change then occurred within the SAP, and the party attempted a 'third way' aimed at the improvement of the profit margin of big enterprises. Financial deregulation was also conducted in Sweden. Reflecting the changed economic situation, from growth to stagnation, the SAP first leaned left, then turned to the right and sided with corporate management.

The bubble burst in 1990. Fujita views 1990 as the year of a sea change when corporatism definitely came to an end in Sweden. The increasing fiscal deficit resulting from social expenditures since the 1960s, the economic stagnation since the 1970s and the pressures of an ageing population and 'new social risk' threatened people's belief in the Swedish model.

Neoliberalism brought not only bad economic performances but also bad political outcomes. A quality democracy must have a stable institutional structure that secures the liberty and equality of its citizens. As argued in Fujita's chapter, one of the most significant policy areas pertaining to substantive equality and solidarity can be promoted by the welfare state. Welfare policy areas are thus crucial for the democratic quality of a polity. In Chapter 14, Sacchi demonstrates how the quality of democracy has been deteriorating for 20 years under the neoliberal policy regime by examining the policies that impact most directly individuals' everyday life, including those related to equality, services and social security. He analyses 
Italy's democratic quality in comparison with that of France, the United Kingdom, Spain and Germany.

In the last 20 years, Italy's unemployment rate has reached 12 per cent in spite of the widespread use of atypical work schemes. The tax burden has also reached new heights. Economic inequality has widened. Younger citizens face an inferior lifestyle in terms of economic security, employment opportunities and educational quality. France, the United Kingdom, Spain and Germany are also witnessing similar trends, but in the Italian case, its government lacks a sufficient policy capacity to break the intergenerational transmission of disadvantage. Sacchi underlines that these outcomes have been brought about by public policy choices made by the political parties in power.

Italy entered the decade of globalization, the 1990s, with major delays in its development compared with the most advanced European countries: France, Germany and the United Kingdom. However, income inequality showed a general decrease in Italy between the early 1970s and the early 1980s. During the 1980s, income inequality remained almost constant and hit a low just before 1992-93. The lira devaluation of September 1992 had a severe impact on those people with lower incomes. According to Sacchi, decision makers faced extremely urgent financial difficulties and they could not fully perceive the distributive effects of their choices.

Sacchi also emphasizes that public policy choices concerning labor market institutions are among the factors that have contributed to income inequality in the advanced countries. By not strengthening social protection while the labor market was being liberalized, policy makers have created flex-insecurity. Their policies were meant to foster social integration but have turned out to be potential drivers of disintegration. He particularly stresses the potential impact of electorates' sheer disaffection with the ongoing policy regime. According to Sacchi, the emerging societal divides are not short-term, transient effects of the Great Recession but rather they are based on deep changes caused by public policy choices the governments had taken throughout the decades under neoliberalism.

In the final chapter, Shiratori introduces a new perspective that should be shared by researchers who specialize in public policy studies and party politics. He demonstrates that there exist various levels of policy regimes: international, national and subnational (regional). He distinguishes these three dimensions of policy regimes to emphasize the mutual impacts among these levels, and he labels policy regimes at the global, national and regional levels as 'international policy regime', 'national policy regime' and 'regional policy regime'.

According to Shiratori, globalization has integrated nation-states into a single worldwide market under neoliberalism. He particularly focuses 
on the reaction from subnational politics. The international policy regime has changed the national policy regime, which again stimulated regional politics. In some subnational cases, regional interests hardly accept the neoliberal changes in the international and the national policy regimes. Neoliberalism causes a harsh resistance. The emergence of new regional parties is a subnational response to the neoliberal policy regime at the international and the national levels.

Shiratori theoretically explores the dynamics of policy regime change by reviewing previous research studies in the field of policy innovation and transfers. He argues that policy transfer during stability is mostly voluntary. However, the process of transfer during a crisis tends to be coercive. He highlights the importance of political parties during a process of policy regime change. According to Shiratori, political parties are the final and most influential political entities that mobilize electorates, exerting their power at all the levels of a policy regime, that is, the international, national and subnational levels. The ruling party can set the tone of the policy regime.

In addition, he refers to the specific effects of the EU. The proposal by the social democratic governments in Sweden and Norway to join the EU in the 1990s meant that this decision would entail changes in their national policy regimes from social democratic to neoliberal. In Japan, neoliberal leader Junichiro Koizumi's reform initiatives resulted in the formation of new parties at the regional and national levels. New parties' attempts to block the neoliberalization of the policy regime ended in vain. However, Shiratori argues that vertical policy transfers, from an international to a national policy regime, may prompt resistance from established subnational political forces. A policy regime change may lead to a party system change. He stresses the need to monitor multilevel policy regimes that have been used to explain the development of regimes.

As suggested in most chapters of this volume, the neoliberal policy regime has placed heavy constraints on each country's policy choices. How different is neoliberalism from liberalism? The shared recognition among the authors of this volume is that neoliberalism is a policy package that is often expressed as the so-called 'Washington Consensus'. We also share a view that no policy regime can always promise good economic performance. In fact, each country has been achieving similarly poor economic performance under the neoliberal policy regime.

As Nishi's chapter shows, the most imperative action for policy makers is to choose a growth regime first, and then pursue the monetary and fiscal policies most appropriate to that growth regime. The political variables such as the bargaining power of labor, the robustness of employment security and the degree of orientation towards redistribution are also key 
factors. Why has the neoliberal policy regime been able to persist for such a long period of time despite its inferiority in terms of policy performance? One interpretation (Przeworski) is that any policy takes time to have an effect, from its formulation to its implementation. Another understanding (Bresser-Pereira, Martinelli and Ido) is that electorates tend to vote under the sway of various 'powers' (very strong influences) that stem from specific dominant economic interests.

Under different policy regimes, either Keynesian or neoliberal, there are a variety of growth regimes, and consequent economic performances will vary considerably.

\section{NOTES}

1. This was demonstrated also in the latest elections in Greece, Spain and France.

2. The Baker Plan of 1985 was said to redefine neoliberal new ideas by adding marketoriented institutional reforms to the orthodox macroeconomic adjustment.

3. The ideas that worldwide liberal markets led by the global capital market promote economic development swept the world. For the concept of the Washington Consensus, see Williamson (1990).

4. International organizations do not always make appropriate policy suggestions. In the 1990s in Brazil, for instance, hyperinflation rapidly spread, although there was no fiscal deficit. According to Sacks and Zini (1996), the Brazilian inflation was caused by the widespread and inertial determination of wages and prices, and thus the inflation could not be remedied by ordinary fiscal austerity. The IMF, however, required a strict austerity package as a condition for financial assistance. For a pro-IMF view that is different from that of Sacks and Zini, see Tullio and Ronci (1996).

5. McMillan and Rodrik (2011) emphasize, however, that such displacement of labor may not affect the productivity of the whole economy if the difference in productivity among sectors is not large or if a high unemployment rate does not persist.

6. The possibility of such a shift is implied also by Birdsall (2011): "There will be a shift - in mind-set and in practical form - from what might be called the "mostly free" market to a "more managed" market version of capitalism' (p. 2).

7. Boyer (2007) emphasizes that modernization of the general welfare is the best response to globalization.

8. Luis Buñuel perhaps attempted in his film El Angel Exterminador (1962) to describe metaphorically people's obsession under authoritarian rule by using the image of el angel exterminador, but the situation in which people believe they cannot leave a room once they have entered it seems to resemble the situation under the neoliberal credo.

\section{REFERENCES}

Amable, B., E. Guillard and S. Palombarini (2012), L'Economie Politique $d u$ Neoliberalisme: Le cas de la France et de L'Italie, Paris: Editions Rue d'Ulm.

Birdsall, N. (2011), 'The global crisis: the beginning of the end of the "Development" Agenda?', in N. Birdsall and F. Fukuyama (eds), New Ideas on Development After the Financial Crisis, Baltimore, MD: Johns Hopkins University Press, pp. 1-26. 
Boyer, R. (2007), 'Growth strategies and poverty reduction: the institutional complementarity hypothesis', Paris School of Economics Working Paper No. 2007-43.

Boyer, R. (2011), 'How policy and economy interact? A Regulationist approach', Paper presented at the 2nd International Symposium on Economic Crises and Policy Regimes, Waseda University, Tokyo, 8 December.

Boyer, R. (2013), 'Origins, unfolding and ways out of the euro crisis: the European Union at the crossroads', Paper presented at the Science Council of Japan, Tokyo, 17 February.

Bresser-Pereira, L.C. (2006), 'The new developmentalism and conventional orthodoxy', Paper presented at the XI Congreso Internacional del CLAD sobre la Reforma del Estado y de la Administracion Publica, Ciudad de Guatemala, 7-10 November.

Bresser-Pereira, L.C. (2010a), Globalization and Competition, New York: Cambridge University Press.

Bresser-Pereira, L.C (2010b), 'Why inequality does not fall?', Peace Review: A Journal of Social Justice, special edition, forthcoming.

Bresser-Pereira, L.C. (2011a), 'Structuralist macroeconomics and the new developmentalism', Unpublished manuscript, 19 October version.

Bresser-Pereira, L.C. (2011b), 'The euro, just a foreign currency?', Folha de S. Paulo, 21 November.

Bresser-Pereira, L.C. (2012), 'Five models of capitalism', Brazilian Journal of Political Economy, 32 (1), 21-32.

Cardini, A. (ed.) (2006), Il miracolo economic italiano (1958-1963), Bologna: il Mulino.

Castronovo, V. (1995), Storia economica d'Italia: Dall'Ottocento ai giorni nostri, Torino: Einaudi Editore.

Castronovo, V. (2010), L'Italia del miracolo economico, Bari: Editori Laterza.

Draibe, S, and N. Riesco (2009), 'Social policy and development in Latin America: the long view', Social Policy and Administration, 43 (4), 328-46.

Hall, P. (1986), Governing the Economy: The Politics of State Intervention in Britain and France, New York: Oxford University Press.

McMillan, M. and D. Rodrik (2011), 'Globalization, structural change, and productivity growth', Unpublished manuscript, February version.

Przeworski, A. (2001), 'How many ways can be third?', in A. Glyn (ed.), Social Democracy in Neoliberal Times: The Left and Economic Policy Since 1980, Oxford: Oxford University Press.

Przeworski, A. (2010), Democracy and the Limits of Self Government, New York: Cambridge University Press.

Przeworski, A., S. Stokes and B. Manin (eds) (1999), Democracy and Accountability, New York: Cambridge University Press.

Rodrik, D. (2009), 'Growth after the crisis', Commission on Growth and Development Working Paper No. 65.

Rodrik, D. (2010), 'Making room for China in the world economy', American Economic Review: Papers and Proceedings, 100, 89-93.

Sacks, J. and A.A. Zini, Jr (1996), 'Brazilian inflation and the Plano Real', The World Economy, 19 (1), 13-37.

Schmitter, P.C. (2013), 'The crisis of the euro, the crisis of the European Union and the crisis of democracy in Europe', First draft, Journal of Democracy, special issue, forthcoming. 
Tullio, G. and M. Ronci (1996), 'Brazilian inflation from 1980 to 1993: causes, consequences and dynamics', Journal of Latin American Studies, 28 (3), 635-66. Vernon, R. (1966), 'International investment and international trade in the product cycle', Quarterly Journal of Economics, 80 (2), 190-207.

Williamson, J. (1990), 'What Washington means by policy reform', in J. Williamson (ed), Latin American Adjustment: How Much has Happened? Washington, DC: Institute for International Economics. 
Hideko Magara - 9781782549925 Downloaded from PubFactory at 04/26/2023 10:01:35AM via free access 